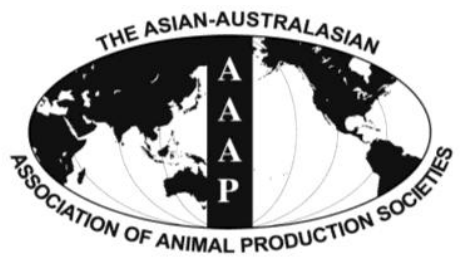

Asian-Aust. J. Anim. Sci.

Vol. 25, No. 9 : 1294 - 1299

September 2012

www.ajas.info

http://dx.doi.org/10.5713/ajas.2011.11403

\title{
Evaluation of the Effect of Low Dietary Fermentable Carbohydrate Content on Growth Performance, Nutrient Digestibility, Blood Characteristics, and Meat Quality in Finishing Pigs
}

\author{
S. M. Hong, J. H. Hwang ${ }^{1}$ and I. H. Kim* \\ Department of Animal Resource and Science, Dankook University, Cheonan, Choongnam, 330-714, Korea
}

\begin{abstract}
A total of 96 pigs $(49.23 \pm 3.20 \mathrm{~kg})$ were used in an $11 \mathrm{wk}$ growth trial to evaluate the effect of fermentable carbohydrate (FC) content on growth performance, apparent total tract digestibility (ATTD) of nutrient, blood profile, and meat quality. The dietary treatments were: i) negative control (NC), basal diet, ii) positive control (PC), NC+antibiotics (positive control diet with 5 ppm flavomycin), iii) PCL, PC-13\% lower FC, and iv) NCL, NC-13\% lower FC. The growth performance (average daily gain, average daily feed intake, and gain/feed) didn't differ among treatments through the whole experiment. These pigs fed the PCL diet had the greater $(\mathrm{p}<0.05)$ apparent total tract digestibility (ATTD) of dry matter than those from PC and NC treatment at the end of the experiment. No differences were observed in white blood cell (WBC), red blood cell (RBC), and lymphocyte concentration among different treatments. After the feeding period, meat samples were collected from the pigs at slaughter. The pigs in NCL and PCL treatments had greater $(p<0.05)$ backfat thickness and lower lean percentage. The color value of loin was higher $(p<0.05)$ in NCL treatment compared to PCL treatment. Also, the NCL treatment had higher $(\mathrm{p}<0.05)$ marbling value than PC treatment. The drip loss was depressed by PCL and NCL treatment comapared to NC treatments. The water holding capacity (WHC) was higher $(\mathrm{p}<0.05)$ in NC and PCL treatment. In conclusion, the low FC can improve digestibility and meat quality of finishing pigs. (Key Words: Blood Profile, Digestibility, Fermentable Carbohydrate, Finishing Pig, Growth Performance, Meat Quality)
\end{abstract}

\section{INTRODUCTION}

Because of the increasing public awareness and objection to the use of antibiotics as growth promoters in animal diets, scientists are searching for the method and alternatives. Based on the simply thoughts that to improve the digestibility of feed and the ability to digest of feed through the better health status of animals themselves. Except from those kinds of potential additives, such as organic acids, probiotics, prebiotics, enzymes, and photogenic extract, the simply high quality feed may also be considered.

Non-starch polysaccharides (NSP) are the main carbohydrates lies in the walls of cereal grains such as, soybean, wheat, rye, tapioca, and triticale. The digestive tracts of nonruminant animals do not contain the enzymes necessary to hydrolyze the NSP, which limited the

\footnotetext{
* Corresponding Author: In Ho Kim. Tel: +82-41-550-3652, Fax: +82-41-565-2949, E-mail: inhokim@dankook.ac.kr

${ }^{1}$ Woosung Feed Co., Ltd. Daejeon, Korea.

Submitted Nov. 2, 2011; Accepted Feb. 29, 2012; Revised Jun. 1, 2012
}

utilization of cheaper cereal grain and their byproducts (Wang et al., 2009a). Fermentation of non-starch polysaccharides in the gut (mainly hindgut) of pigs results in the formation of short chain fatty acids (VFA). Experimental data show that growing and fattening pigs can cover about 17 to $24 \%$ of their maintenance requirement for energy via the metabolism of VFA, while sows can even cover up to 25 to 35\% (Rérat et al., 1987; Shi and Noblet, 1993; Johnston et al., 2002). Dietary fermentable carbohydrates (FC), as part of the NSP, decrease the dressing percentage and the backfat thickness (Zhu et al., 1990; Shriver et al., 2003). The former indicates that VFA resulting from an increased fermentation in the digestive tract may alter the body composition of pigs. It is also said that reducing CP content and increasing FC level may counteract the negative effects of protein fermentation in weaning pigs fed high CP diets (Bikker et al., 2006). Because of high fiber content in DDGS and limited concentration of fiber degrading enzymes in the intestinal system of nonruminants, the $3.5 \%$ of distiller's dried grains with soluble (DDGS) were used in the high CP treatment as the control. 
Therefore, one experiment is conducted to evaluate the effects of the lower level of fermentable carbohydrates inclusion to antibiotics-free diet of finishing pigs on growth performance, nutrient digestibility, blood profile, and meat quality.

\section{MATERIALS AND METHODS}

\section{Animal and experimental design}

The protocols used for the current experiment were approved by the Animal Care and Use Committee of Dankook University.

A total of 96 crossbred pigs [(Landrace $\times$ Yorkshire $) \times$ Duroc] with an average initial BW of $49.23 \pm 3.20 \mathrm{~kg}$ were selected for this $11 \mathrm{wks}$ growth assay. Pigs were allocated to one of four treatments according to their BW and sex with six replicates per treatment and four pigs per pen (two gilts and two barrows). The dietary treatments were: i) negative control (NC), basal diet, ii) positive control (PC), NC+antibiotics (positive control diet with 5ppm flavomycin), iii) PCL, PC-13\% lower FC, and iv) NCL, NC-13\% lower FC. All nutrient diets were formulated to exceed or met National Research Council (NRC, 1998) recommendation (Table 1). Pigs were housed in an environmentally controlled, slatted-floor facility in 24 adjacent pens $(1.8 \times 1.8 \mathrm{~m})$ and were allowed ad libitum access to feed and water.

\section{Data and sampling collection}

For the growth assay, the pig weights and feed disappearance were recorded weekly to calculate the average daily gain (ADG), average daily feed intake (ADFI), and gain/feed (G/F). Chromium oxide $(0.20 \%)$ was added as an inert indicator to calculate the apparent digestibility of DM and N. After the pigs were fed the diets containing the indicator for $7 \mathrm{~d}$, fresh fecal grab samples were obtained from each pen at 0800. The fecal samples were then dried at $50^{\circ} \mathrm{C}$ for $72 \mathrm{~h}$ and finely ground to be able to pass through a $1 \mathrm{~mm}$ screen. All of the feed and feces samples were then frozen at $-20^{\circ} \mathrm{C}$ until further analysis. After the concentration of dry matter (DM) and nitrogen (N) was determined (AOAC, 2000), the DM and N digestibilities were calculated according to the indicator method, with the concentration of chromium being analyzed by UV absorption spectrophotometry (Shimadzu, UV-1201, Japan) following the method described by Williams et al. (1962). The gross energy in the feed and feces was determined using calorimeter (Mode 1241, Parr Instrument Co., USA).

For the blood characteristics assay, two pigs were randomly selected from each pen and venous blood samples were collected into both nonheparinized tubes and vacuum tubes containing $\mathrm{K}_{3}$ EDTA (Becton, Dickinson and Co.,
Table 1. Compositions of basal finishing pig diets (as-fed basis) ${ }^{1}$

\begin{tabular}{lcccc}
\hline Item $(\%)$ & NC & PC & PCL & NCL \\
\hline Corn & 33.51 & 33.42 & 36.96 & 37.15 \\
Wheat & 25.00 & 25.00 & 25.00 & 25.00 \\
Soybean meal & 16.58 & 16.64 & 19.40 & 19.37 \\
$\quad$ (45\% of CP) & & & & \\
Rice bran & 8.00 & 8.00 & 8.00 & 8.00 \\
Wheat bran & 0.80 & 0.80 & - & - \\
Canola meal & 2.00 & 2.00 & - & - \\
DDGS & 3.50 & 3.50 & - & - \\
Limestone & 0.69 & 0.56 & 0.83 & 0.76 \\
Tallow & 4.15 & 4.20 & 4.10 & 4.07 \\
Molasses cane & 4.00 & 4.00 & 4.00 & 4.00 \\
NaCl & 0.30 & 0.30 & 0.30 & 0.30 \\
DL-met (99\%) & 0.01 & 0.01 & 0.06 & 0.06 \\
L-lys (78\%) & 0.20 & 0.20 & 0.22 & 0.22 \\
Dicalcium phosphate & 0.46 & 0.48 & 0.23 & 0.26 \\
Premix & 0.80 & 0.80 & 0.80 & 0.80 \\
Flavomycin (5 g/kg) & - & 0.10 & 0.10 & - \\
Analyzed composition & & & & \\
$\quad$ Crude protein $(\%)$ & 16.50 & 16.50 & 15.71 & 15.69 \\
Ether extract (\%) & 7.75 & 7.86 & 7.52 & 7.54 \\
Crude fibre (\%) & 4.05 & 4.28 & 3.19 & 3.19 \\
Ash (\%) & 4.81 & 5.05 & 4.45 & 4.61 \\
Ca (\%) & 0.63 & 0.62 & 0.59 & 0.69 \\
P (\%) & 0.58 & 0.57 & 0.46 & 0.51 \\
Lys (\%) & 0.96 & 0.96 & 0.96 & 0.96 \\
Met (\%) & 0.29 & 0.29 & 0.31 & 0.31 \\
FC (g/kg) & 129.03 & 127.45 & 110.00 & 110.00 \\
NSP (g/kg) & 145.0 & 145.0 & 130.0 & 130.0 \\
\hline
\end{tabular}

${ }^{1}$ Each mean represents 6 pens with 4 pigs each per treatment. Dietary treatments were as follows: $\mathrm{NC}=$ Negative control diet; $\mathrm{PC}=$ Control diet with $5 \mathrm{mg} / \mathrm{kg}$ Flavomycin; PCL = PC-low FC; NCL = NC-low FC.

${ }^{2}$ The vitamin and mineral premix supplied per $1 \mathrm{~kg}$ of the diet: 4,000 IU of vitamin A, $800 \mathrm{IU}$ of vitamin $\mathrm{D}_{3}, 15 \mathrm{IU}$ of vitamin $\mathrm{E}, 4 \mathrm{mg}$ of riboflavin, $15 \mu \mathrm{g}$ of vitamin $\mathrm{B}_{12}, 10 \mathrm{mg}$ of d-pantothenic acid, $20 \mathrm{mg}$ of niacin, $15 \mathrm{mg}$ of $\mathrm{Cu}$ from $\mathrm{CuSO}_{4} \cdot 5 \mathrm{H}_{2} \mathrm{O}, 90 \mathrm{mg}$ of $\mathrm{Fe}$ from $\mathrm{FeSO}_{4} \cdot 7 \mathrm{H}_{2} \mathrm{O}$, $40 \mathrm{mg}$ of $\mathrm{Mn}$ from $\mathrm{MnO}_{2}, 40 \mathrm{mg}$ of $\mathrm{Zn}$ from $\mathrm{ZnSO}_{4} \cdot \mathrm{H}_{2} \mathrm{O}, 0.2 \mathrm{mg}$ of $\mathrm{Se}$ from $\mathrm{Na}_{2} \mathrm{SeO}_{3} \cdot 5 \mathrm{H}_{2} \mathrm{O}, 0.5 \mathrm{mg}$ of $\mathrm{Co}$ from $\mathrm{CoSO}_{4} \cdot 7 \mathrm{H}_{2} \mathrm{O}$.

Franklin Lakes, NJ, USA) to obtain serum and whole blood, respectively. After collection, serum samples were centrifuged $(2,000 \times \mathrm{g})$ for $30 \mathrm{~min}$ at $4{ }^{\circ} \mathrm{C}$. Serum total protein was determined using an automatic biochemistry analyzer (HITACHI 747, Hitachi, Tokyo, Japan). The white blood cells (WBC), red blood cells (RBC) and lymphocyte percentage in the whole white blood were determined using an automatic blood analyzer (ADVIA 120, Bayer, NY, USA).

Two pigs of each pen were slaughtered when average BW in the heaviest pen of the weight block reached $110 \mathrm{~kg}$ and back fat, muscle percentage and lean ratio measurement was performed using a real time ultrasound instrument (Piglot 105, SFK Technology, Herlev, Denmark). After chilling at $2^{\circ} \mathrm{C}$ for $24 \mathrm{~h}$, one 2.54 -cm-thick longissimus 
muscle (LM) sample was abstained at the 10th rib (right side of the carcass). Sensory evaluation (color, marbling and firmness scores) was evaluated according to National Pork Producers Council standards (NPPC, 2000). Drip loss was determined as a percentage of the original weight using $2 \mathrm{~g}$ of meat sample according to the method of Honikel (1998). Duplicate $\mathrm{pH}$ values of each sample were measured via an glass-electrode $\mathrm{pH}$ meter (WTW pH 340-A, WTH Measurement Systems Inc., Ft. Myers, FL). Water holding capacity (WHC) was measured followed the guide of Kauffman et al. (1986). Longissimus muscle area (LMA) was measured by tracing the longissimus muscle surface at the 10th rib, which also used the above mentioned digitizing area-line sensor. The last rib backfat thickness (measured on the midline of the split carcass) for each pig were adjusted (using regression analysis) to the average final $\mathrm{BW}$ before being pooled using the equation proposed by the National Pork Producers Council (NPPC, 2000).

\section{Statistical analysis}

All data generated in this experiment were subjected to the GLM procedures of SAS (SAS Institute, 2001) as a randomized complete block design. Each pen served as the experimental unit. Additionally, Duncan's multiple range test was used to compare the means of the treatments (Duncan, 1955). Variability in the data was expressed as the pooled standard error (SE) and a $\mathrm{p}<0.05$ was considered to be statistically significant.

\section{RESULTS}

\section{Growth performance}

The ADG, ADFI, and G/F were unaffected by the

Table 2. Effect of low fermentable carbohydrates (FC) on growth performance of finishing pigs ${ }^{1}$

\begin{tabular}{|c|c|c|c|c|c|}
\hline Items & $\mathrm{NC}$ & $\mathrm{PC}$ & PCL & $\mathrm{NCL}$ & $\mathrm{SE}^{2}$ \\
\hline \multicolumn{6}{|l|}{0 to $35 \mathrm{~d}$} \\
\hline $\mathrm{ADG}(\mathrm{g})$ & 739 & 761 & 797 & 795 & 36 \\
\hline ADFI (g) & 1,840 & 1,898 & 1,915 & 1,870 & 62 \\
\hline FCR & 2.490 & 2.494 & 2.403 & 2.352 & 0.14 \\
\hline \multicolumn{6}{|l|}{36 to $77 \mathrm{~d}$} \\
\hline $\mathrm{ADG}(\mathrm{g})$ & 735 & 755 & 799 & 793 & 35 \\
\hline ADFI v & 2,190 & 2,305 & 2,290 & 2,318 & 88 \\
\hline FCR & 2.980 & 3.053 & 2.866 & 2.923 & 0.13 \\
\hline \multicolumn{6}{|l|}{0 to $77 \mathrm{~d}$} \\
\hline $\mathrm{ADG}(\mathrm{g})$ & 737 & 758 & 798 & 794 & 30 \\
\hline ADFI (g) & 2,015 & 2,101 & 2,103 & 2,094 & 66 \\
\hline FCR & 2.734 & 2.772 & 2.635 & 2.637 & 0.11 \\
\hline \multicolumn{6}{|c|}{$\begin{array}{l}\mathrm{a,b} \text { Within a row, mean with different superscripts differ }(\mathrm{p}<0.05) \text {. } \\
{ }^{1} \text { Each mean represents } 6 \text { pens with } 4 \text { pigs each per treatment. Dietary } \\
\text { treatments were as follows: NC }=\text { Negative control, basal diet; PC }=\mathrm{NC} \\
\text { with } 5 \mathrm{mg} / \mathrm{kg} \text { Flavomycin; PCL }=\mathrm{PC}-13 \% \text { lower } \mathrm{FC} ; \mathrm{NCL}=\mathrm{NC}-13 \% \\
\text { lower FC. }\end{array}$} \\
\hline
\end{tabular}

Table 3. Effect of low fermentable carbohydrates (FC) on nutrient digestibility of finishing pigs ${ }^{1}$

\begin{tabular}{lccccc}
\hline Items & NC & PC & PCL & NCL & SE $^{2}$ \\
\hline $35 \mathrm{~d}$ & & & & & \\
$\quad$ DM & 77.84 & 78.14 & 80.37 & 79.66 & 0.79 \\
Nitrogen & 75.57 & 76.49 & 77.10 & 76.59 & 1.25 \\
Energy & 76.33 & 77.44 & 78.80 & 77.92 & 0.98 \\
77 d & & & & & \\
DM & $74.50^{\mathrm{b}}$ & $74.64^{\mathrm{b}}$ & $77.11^{\mathrm{a}}$ & $76.28^{\mathrm{ab}}$ & 0.67 \\
Nitrogen & 72.66 & 72.08 & 74.56 & 74.20 & 0.87 \\
Energy & 73.75 & 73.41 & 76.43 & 75.85 & 0.96 \\
\hline
\end{tabular}

${ }^{\mathrm{a}, \mathrm{b}}$ Within a row, mean with different superscripts differ $(\mathrm{p}<0.05)$.

${ }^{1}$ Each mean represents 6 pens with 4 pigs each per treatment. Dietary treatments were as follows: $\mathrm{NC}=$ Negative control, basal diet; $\mathrm{PC}=\mathrm{NC}$ with $5 \mathrm{mg} / \mathrm{kg}$ Flavomycin; PCL $=$ PC-13\% lower FC; NCL $=\mathrm{NC}-13 \%$ lower FC.

${ }^{2}$ Pooled standard errors.

dietary treatments throughout the whole experiment (Table 2).

\section{Apparent total tract digestibility of nutrient}

The PCL treatment had the greater $(\mathrm{p}<0.05)$ ATTD of DM than PC and NC treatments at $\mathrm{d} 77$ (Table 3).

\section{Blood characteristics}

No differences have been observed in WBC, RBC, and lymphocyte concentration (Table 4).

\section{Meat quality}

The effects of FC on the meat quality were presented in Table 5. The pigs in NCL and PCL treatments had greater $(p<0.05)$ backfat thickness and lower lean percentage. The color value of loin was higher $(p<0.05)$ in NCL treatment related to PCL treatment. Also, the NCL treatment had higher $(\mathrm{p}<0.05)$ marbling value than $\mathrm{PC}$ treatment. The drip loss was depressed by PCL and NCL treatment than NC

Table 4. Effect of low fermentable carbohydrates (FC) on blood characteristics of finishing pigs ${ }^{1}$

\begin{tabular}{lccccc}
\hline Items & NC & PC & PCL & NCL & SE $^{2}$ \\
\hline WBC, $10^{3} / \mu \mathrm{l}$ & & & & & \\
$\quad 35 \mathrm{~d}$ & 6.57 & 6.83 & 6.50 & 6.82 & 0.19 \\
$77 \mathrm{~d}$ & 6.99 & 7.19 & 7.10 & 7.29 & 0.24 \\
RBC, $10^{6} / \mu \mathrm{l}$ & & & & & \\
$\quad 35 \mathrm{~d}$ & 19.71 & 17.35 & 17.77 & 17.93 & 1.15 \\
$77 \mathrm{~d}$ & 19.29 & 18.74 & 18.31 & 19.05 & 0.79 \\
Lymphocyte (\%) & & & & & \\
$35 \mathrm{~d}$ & 50.73 & 52.20 & 54.83 & 53.10 & 2.61 \\
$77 \mathrm{~d}$ & 59.39 & 63.35 & 60.62 & 62.57 & 2.18 \\
\hline
\end{tabular}

${ }^{1}$ Each mean represents 6 pens with 4 pigs each per treatment. Dietary treatments were as follows: $\mathrm{NC}=$ Negative control, basal diet; $\mathrm{PC}=\mathrm{NC}$ with $5 \mathrm{mg} / \mathrm{kg}$ Flavomycin; PCL $=$ PC-13\% lower FC; NCL $=\mathrm{NC}-13 \%$ lower FC.

${ }^{2}$ Pooled standard errors. 
Table 5. Effect of low fermentable carbohydrates (FC) on meat quality of finishing pigs ${ }^{1}$

\begin{tabular}{|c|c|c|c|c|c|}
\hline Items & $\mathrm{NC}$ & $\mathrm{PC}$ & PCL & $\mathrm{NCL}$ & $\mathrm{SE}^{2}$ \\
\hline \multicolumn{6}{|l|}{ Color } \\
\hline L* (Lightness) & 56.04 & 54.29 & 56.22 & 55.17 & 1.52 \\
\hline $\mathrm{a}^{*}$ (Redness) & 16.8 & 16.96 & 17.22 & 17.35 & 0.39 \\
\hline $\mathrm{b}^{*}$ (Yellowness) & 7.64 & 6.92 & 7.78 & 8.19 & 0.63 \\
\hline \multicolumn{6}{|l|}{ Sensory evaluation ${ }^{3}$} \\
\hline Color & $1.7^{\mathrm{bc}}$ & $1.7^{\mathrm{ab}}$ & $1.6^{\mathrm{c}}$ & $1.8^{\mathrm{a}}$ & 0.04 \\
\hline Marbling & $1.8^{\mathrm{ab}}$ & $1.7^{\mathrm{b}}$ & $1.8^{\mathrm{ab}}$ & $1.9^{\mathrm{a}}$ & 0.08 \\
\hline Firmness & 1.7 & 1.8 & 1.9 & 1.8 & 0.07 \\
\hline \multicolumn{6}{|l|}{ Drip loss $(\%)$} \\
\hline $1 \mathrm{~d}$ & 4.1 & 5.8 & 4.5 & 4.3 & 0.82 \\
\hline $3 \mathrm{~d}$ & $2.5^{\mathrm{b}}$ & $3.0^{\mathrm{ab}}$ & $4.1^{\mathrm{a}}$ & $4.2^{\mathrm{a}}$ & 0.49 \\
\hline $5 \mathrm{~d}$ & 2.2 & 3.1 & 3.1 & 3.0 & 0.43 \\
\hline $7 \mathrm{~d}$ & 0.9 & 0.9 & 1.1 & 0.7 & 0.22 \\
\hline $\mathrm{pH}$ & 5.6 & 5.5 & 5.6 & 5.6 & 0.04 \\
\hline Water holing capacity $(\%)$ & $40.0^{\mathrm{a}}$ & $35.4^{\mathrm{b}}$ & $40.6^{\mathrm{a}}$ & $38.0^{\mathrm{ab}}$ & 1.05 \\
\hline Lean muscle area $\left(\mathrm{cm}^{2}\right)$ & $64.3^{\mathrm{a}}$ & $62.6^{\mathrm{a}}$ & $58.3^{\mathrm{b}}$ & $57.6^{\mathrm{b}}$ & 1.62 \\
\hline \multicolumn{6}{|l|}{ Backfat thickness (mm) } \\
\hline $0 \mathrm{~d}$ & 9.0 & 8.9 & 8.9 & 8.8 & 0.20 \\
\hline $35 \mathrm{~d}$ & 10.8 & 11.3 & 11.3 & 11.0 & 0.29 \\
\hline $77 \mathrm{~d}$ & $12.7^{\mathrm{b}}$ & $12.5^{\mathrm{b}}$ & $14.2^{\mathrm{a}}$ & $14.0^{\mathrm{a}}$ & 0.38 \\
\hline
\end{tabular}

${ }_{\mathrm{a}, \mathrm{b}}$ Within a row, mean with different superscripts differ $(\mathrm{p}<0.05)$.

${ }^{1}$ Each mean represents 6 pens with 4 pigs each per treatment. Dietary treatments were as follows: $\mathrm{NC}=$ Negative control, basal diet; $\mathrm{PC}=\mathrm{NC}$ with 5 $\mathrm{mg} / \mathrm{kg}$ Flavomycin; PCL = PC-13\% lower FC; NCL = NC-13\% lower FC.

${ }^{2}$ Pooled standard errors.

${ }^{3}$ According to the NPPC (2000) that is determined on a freshly-cut surface on the color scale of 1 to 5); Firmness (3 or greater on the scale of 1 to 5); Marbling (3 or greater on the scale of 1 to 5 ).

treatments. The WHC was higher $(\mathrm{p}<0.05)$ in NC and PCL treatments.

\section{DISCUSSION}

In the current study, the growth performance was not affected by the levels of FC and the antibiotics inclusion, but the lower levels $(-13 \%)$ of FC were shown to increase the DM digestibility. The fermentable carbohydrate, which can't be well utilized by the non-ruminant because of the insufficient secretion of endogenous enzymes, may serve as the energy for microbial when moving to the large intestine. This increasing microbial can compete the nutrients and energy with the host (Shriver et al., 2003; Wang et al., 2009b). Meanwhile, FC may depress the digestibility of other nutrient by increasing the viscosity of the gastrointestinal digesta. Through this mechanism, the lower FC may have higher digestibility of DM than higher FC. This is partly consistent with our result. However this effect is not so obvious (only in $77 \mathrm{~d}$ ) when come to the finishing pigs. This may due to that the finishing pig is in a relatively physiological maturity stage through the whole life of the swine, which may tolerate the certain levels of FC in their feed. Similarly, Shriver et al. (2003) found that the different FC levels cause no differences for growth performance of finishing pigs. In this study, the author lowered the CP levels by addition of fiber source (10\% of soybean hull), and found no difference in nitrogen intake, absorption, and retention too. Similarly, Kornegay (1981) reported that the addition of up to $15 \%$ soybean hull to the diet of growingfinishing pigs did not affect growth performance. Shriver et al. (1999) and Knowles et al. (1998) suggested that up to $20 \%$ wheat middling may be added to finishing pigs diets without affecting growth performance. On contrary, Hansen et al. (2008) reported that the addition of $25 \%$ lupine in the diet had a negative effect on pig performance (growth rate and feed conversion). This inconsistent result may due to the high the high levels of FC. For example, Fernandez and Danielsen (2006) found that by inclusion of $12.5 \%$ lupines (same variety, Prima) observed no affect on performance whereas they by inclusion of $25 \%$ observed a negative effect. The authors also concluded that if less than $15 \%$ of lupine was added to the diet the negative effects of the supplementation on performance could be avoided.

Furthermore, a positive effect of antibiotics on growth responses may occurs primarily as a result of its specific antimicrobial activity, which may be more evident when animals are raised in an inferior hygienic environment. Therefore, the lack of a growth response to antibiotics in the present experiment may also be a result of pigs having a 
high health status and being reared in a hygienic environment.

As the largest immunologically competent organ in the body, the gastrointestinal system and its associated lymphoid is the largest immunologically competent organ in the body, and maturation and optimal development of the immune system after birth depend on the development and composition of the indigenous microflora and vice versa (Michael and Marteau, 2007). The short-chain organic acid can modify the immunity-related blood profile (WBC and lymphocyte concentration) in both weaning and growing pig (Wang et al., 2009b). It is also maybe associated with that a reduction in subclinical infections because of their antimicrobial effects may contribute to improved nutrient digestibility and a reduction in the demand for nutrients by the gut-associated immune tissue.

It is evident that the high dietary FC content reduced the backfat thickness and therefore increases the lean percentage (Zhu et al., 1990; Shriver et al., 2003; Szabó et al., 2007). This is consistent with the result of our study. The dietary lysine to energy ratio primarily determines the rate of protein and fat deposition. In the present study diets were formulated to have a similar ratio of apparently ileal digestible lysine to the net energy. Therefore, the suggested underestimation of the energetic value of treatment with the high FC diet, should affect the protein deposition in the body as well. Möhn et al. (2000) reported, that reduced energy intake decrease the protein deposition in the body. Acetyl CoA is a metabolite shared in common by the metabolism of glucose, fatty acids and some amino acids. The carbon atoms in acetyl $\mathrm{CoA}$ can arise from carbohydrate via pyruvic acid produced in the glycolysis or the catabolism of fatty acids and certain amino acids. Acetyl CoA is the fuel for the Krebs-cycle, which provides most of the energy needs of the cells. If the energy level of the cell is high because of carbohydrate catabolism, the flow of acetyl CoA into the Krebs cycle will be slowed down, and acetyl CoA could be diverted into the synthesis of fatty acids (lipid) (Conn et al., 1987). Fatty acids can be metabolized into triglycerides, which are transported as lipoproteins into the adipose tissue for storage and muscle for energy supply. Cells can utilize the triglycerides as energy source when they are degraded into free fatty acids and glycerol. This process is regulated by lipoprotein lipase. Under isocaloric conditions, this enzyme has a high level of activity in adipose tissue. However, in the case of a low energy supply, lipoprotein lipase is highly active in muscle, liver, and cardiac tissues. These mechanisms can explain why body fatness was clearly affected by VFA, whereas body protein deposition and content are not affected (Szabó et al., 2007).

The different levels of FC had no effects on the $\mathrm{pH}$ and colors $\left(\mathrm{L}^{*}, \mathrm{a}^{*}\right.$, and $\left.\mathrm{b}^{*}\right)$, firmness which is the same with the result form Hansen et al. (2008). Typically, the consumptions of diets with high energy levels or fat tends to increase backfat thickness (Pettigrew and Moser, 1991), but no effects on any pork quality trait such as $\mathrm{pH}$, drip loss, firmness, American color score (Apple et al., 2004). Previous studies also demonstrated that formulating diets based on $\mathrm{CP}$, and energy has no effect on ultimate muscle $\mathrm{pH}$, drip loss percent, WHC, subjective color scores, and firmness scores (Goerl et al., 1995; Witte et al., 2000). We found that that the lower FC can decrease the color and increase of the drip loss of the meat. This may explained by the $\mathrm{pH}$ and lactate in the meat (Pö sö and Puolanne, 2005). Therefore, further experiment is necessary to determine the lactate content in the muscle.

In conclusion, containing lower fermentable carbohydrates $(13 \%$ lower) can improve the nutrient digestibility but have no effects on the growth performance. Lean tissue percentage, however, can be improved as a consequence to the reduced overall fat content of the body.

\section{REFERENCES}

AOAC. 1995. Official method of analysis. 16th edn. Association of Official Analytical Chemists, Washington, DC, USA.

Apple, J. K., C. V. Maxwell, D. C. Brown, K. G. Friesen, R. E. Musser, Z. B. Johnson and T. A. rmstrong. 2004. Effects of dietary lysine and energy density on erformance and carcass characteristics of finishing pigs fed ractopamine. Anim. Sci. 82:3277-3287.

Bikker, P., A. Dirkzwager, J. Fledderus, P. Trevisi, I. le HuërouLuron, J. P. Lallës and A. Awati. 2006. The effect of dietary protein and fermentable carbohydrates levels on growth performance and intestinal characteristics in newly weaned piglets. J. Anim. Sci. 84:3337-3345.

Conn, E. E., P. K. Stumpf, G. Bruening and R. H. Doi. 1987. Outlines of biochemistry. John Wiley \& Sons Inc., New York pp. 393-446.

Ducan, D. B. 1955. Multiple range and multiple $F$ tests. Biometrics 11:1-42.

Fernandez, J. A. and V. Danielsen. 2006. Reduceret protein i foderet til $\emptyset$ kologiske slagtesvin fodret med forskellige maengderlupin. DJF-Report No. 73.

Goerl, K. F., S. J. Eilert, R. W. Mandigo, H. Y. Chen and P. S. Miller. 1995. Pork characteristics as affected by two populations of swine and six crude protein levels. J. Anim. Sci. 73:3621-3626.

Hansen, L. L., S. Stolzenbach, J. A. Jensen, P. Henckel, J. HansenMøller, K. Syriopolos and D. V. Byrne. 2008. Effect of feeding fermentable fibre-rich feedstuff on meat quality with emphasis on chemical and sensory boar taint in entire male and female pigs. Meat Sci. 80:1165-1173.

Honikel, K. O. 1998. Reference methods for the assessment of physical characteristics of meat. Meat Sci. 49:447-457.

Johnston, L. J., A. Renteria and J. Shurson. 2002. Fiber nutrition of sows. In: Proc. 63rd Minnesota Nutrition Conf. Eagan, MN. pp. 217-231.

Kauffman, R. G., G. Eikelenboom, P. G. van der Wal, B. Engel 
and M. Zaar. 1986. A comparison of methods to estimate waterholding capacity in post-rigor porcine muscle. Meat Sci. 18:307-322.

Knowles, T. A., L. L. Southern, T. D. Bidner, B. J. Kerr and K. G. Friesen. 1998. Effect of dietary fiber or fat in low-crude protein, crystalline amino acid-supplemented diets for finishing pigs. J. Anim. Sci. 76:2818-2832.

Kornegay, E. T. 1981. Soybean hull digestibility by sows and feeding value for growing-finishing swine. J. Anim. Sci. 53:138-145.

Michael de, V. and P. R. Marteau. 2007. Probiotics and prebiotics: effects on diarrhea. J. Nutr. 137:803-811.

Möhn, S., A. M. Gillis, P. J. Moughan and C. F. M. de Lange. 2000. Influence of dietary lysine and energy intakes on body protein deposition and lysine utilization int he growing pig. J. Anim. Sci. 78:1510-1519.

NRC. 1998. Nutrient requirements of swine. 10th rev. ed. Natl. Acad. Press, Washington, DC, USA.

NPPC. 2000. Pork composition and quality assessment procedures. In: National (Ed. E. P. Berg). Pork Producers Council. Des Monies, IA, pp. 1-38.

Pettigrew, J. E., Jr. and R. L. Moser. 1991. Fat in swine nutrition. In: Swine Nutrition (Ed. R. Miller, D. E. Ullrey and A. J. Lewis). pp. 133-146. Butterworth-Heinemann, Stoneham, MA.

Pösö, A. R. and E. Puolanne. 2005. Carbohydrate metabolism in meat animals. Meat Sci. 70:423-434.

Rérat, A., M. Fiszlewicz, A. Giusi and P. Vaugelade. 1987. Influence of meal frequency on postprandial variations in the production and absorption of volatile fatty acids in the digestive tract of conscious pigs. J. Anim. Sci. 64:448-456.

SAS Institute. 2001. SAS user's guide. Version 8 ed.SAS Inst. Inc., Cary NC, USA.

Shi, X. S. and J. Noblet. 1993. Contribution of the hindgut to digestion of diets in growing pigs and adult sows: Effect of diet composition. Livest. Prod. Sci. 34:237-252.
Shriver, J. A., S. D. Carter, B. W. Senne and L. A. Pettey. 1999. Effects of adding wheat midds to low crude protein, amino acid supplemented diets for finishing pigs. J. Anim. Sci. 77 (Suppl.1):189(Abstr.).

Shriver, J. A., S. D. Carter, A. L. Sutton, B. T. Richert, B. W. Senne and L. A. Pettey. 2003. Effects of adding fiber sources to reduced-crude protein, amino acid-supplemented diets on nitrogen excretion, growth performance, and carcass traits of finishing pigs. J. Anim. Sci. 81:492-502.

Szabó, C., A. J. M. Jansman, L. Babinszky and M. W. A. Verstegen. 2007. The effect of high dietary fermentable carbohydrate content on the fattening performance and chemical body composition of fattening pigs. Scientific and Professional Review. 13:1-7.

Wang, J. P., S. M. Hong, L.Yan, J. S. Yoo, J. H. Lee, H. D. Jang, H. J. Kim and I. H. Kim. 2009a. Effect of single or carbohydrates cocktail in low-density diets on growth performance, nutrient digestibility, blood characteristics, and carcass traits in growing-finishing pigs. Livest. Sci. 126:215-220.

Wang, J. P., J. S. Yoo, J. H. Lee, H. D. Jang, H. J. Kim, S. S. Seong and I. H. Kim. 2009. Effects of phenyllactic acid on growth performance, nutrient digestibility, microbial shedding, and blood profile in pigs. J. Anim. Sci. 87:3235-3243.

Williams, C. H., D. J. David and O. Iismaa. 1962. The determination of chromic oxide in faeces samples by atomic absorption spectrophotometery. J. Agric. Sci. 59:381-385.

Witte, D. P., M. Ellis, F. K. McKeith and E. R. Wilson. 2000. Effect of dietary lysine level and environmental temperature during the finishing phase on the intramuscular fat content of pork. J. Anim. Sci. 78:1272-1276.

Zhu, J. Q., V. R. Fowler and M. F. Fuller. 1990. Digestion of unmolassed sugar beet pulp in young growing pigs and implications for the growth-supporting values of fermented energy. Anim. Prod. 50:531-539. 